\title{
PREVALENCE AND GENETIC CHARACTERIZATION OF Cryptosporidium spp. and Cystoisospora belli IN HIV-INFECTED PATIENTS
}

\author{
Dnieber Chagas ASSIS(1), Deisy Vivian RESENDE(1), Marlene CABRINE-SANTOS(2), Dalmo CORREIA(2,3) \& Márcia Benedita OLIVEIRA-SILVA(2)
}

\begin{abstract}
SUMMARY
Cryptosporidium spp. and Cystoisospora belli are monoxenic protozoa that have been recognized as the causative agents of chronic diarrhea in immunocompromised individuals, especially HIV-infected subjects. The objective of this study was to evaluate the frequency of these intestinal protozoa in HIV-positive patients in the Triângulo Mineiro region of Brazil and to correlate the presence of these infections with clinical, epidemiological and laboratory data of the patients. Oocysts were detected in stool samples of $10(16.9 \%)$ of the 59 patients studied, while Cryptosporidium spp. were present in $10.1 \%$ (6/59) and C. belli in 6.7\% (4/59). The frequency of these parasites was higher among patients with diarrheic syndrome and CD4+ $\mathrm{T}$ lymphocyte counts $<200$ cells/ $\mathrm{mm}^{3}$, demonstrating the opportunistic characteristic of these infections. A significant association was observed between the lack of adherence to antiretroviral therapy and the presence of Cryptosporidium spp. and/or C. belli. Parasitism with Cryptosporidium spp. was more frequent in February and April, the months following the period of high rainfall. The same was not observed for C. belli. Genetic characterization of two isolates led to the identification of Cryptosporidium parvum, one of the main species associated with the zoonotic transmission of cryptosporidiosis.
\end{abstract}

KEYWORDS: Cryptosporidium spp.; Cystoisospora belli; Genetic characterization; HIV; Infectious diseases.

\section{INTRODUCTION}

Since the beginning of the AIDS pandemic, opportunistic infections have been recognized as common complications of the HIV infection ${ }^{8,29}$. The rapid dissemination of this virus contributed to the increasing prevalence of opportunistic protozoa among HIV-infected patients, with Cryptosporidium spp. and Cystoisospora belli being the most relevant species. The clinical manifestations of the disease caused by these protozoa range from self-limited diarrhea, steatorrhea, headache, abdominal pain, fever and weight loss in immunocompetent individuals to chronic diarrhea, cachexy, electrolyte disorders and death in children and adults with immune diseases ${ }^{14}$.

Despite their cosmopolitan distribution, intestinal protozoa are more prevalent in tropical and subtropical regions where the climate and sanitary conditions contribute to their maintenance. In Brazil, the prevalence of cryptosporidiosis and cystoisosporosis among HIV-infected patients ranges from $6.4 \%$ to $9.1 \%$ and from $4.4 \%$ to $18 \%$, respectively $1,2,6,7,11,16,18$. OLIVEIRA-SILVA et al. ${ }^{19}$ investigated the frequency of these parasites in HIV-infected patients living in the Triângulo Mineiro region and found a prevalence of $8.6 \%$ for Cryptosporidium sp. and of $10.3 \%$ for C. belli.

Despite the great number of reports about the occurrence of
Cryptosporidium infection in HIV (+) patients from Brazil, only a few studies have performed the molecular characterization of the isolates found in the fecal samples. Most of these published papers have shown that $C$. parvum and C. hominis are the most prevalent species ${ }^{1,15,25}$. With respect to $C$. belli, only one study demonstrated genetic polymorphisms among clinical isolates obtained from $\mathrm{HIV}(+)$ patients ${ }^{23}$. Additionally, two isolates were obtained from the same patient with extraintestinal cystoisosporosis, which supports the existence of mixed infection or specific populations which are able to invade and multiply in different host tissues.

The present study evaluated the prevalence of the intestinal protozoa Cryptosporidium spp. and C. belli among HIV-infected patients who were referred to the hospital of the Universidade Federal do Triângulo Mineiro (UFTM), and the possible association between clinical, epidemiological and laboratory data and these parasitic infections. In addition, clinical isolates were characterized genetically by nested PCR-RFLP of the SSU-rRNA gene of Cryptosporidium spp. and by PCR-RFLP of the SSU-rRNA gene of $C$. belli.

\section{MATERIALS AND METHODS}

Samples: Between January and August 2005, 120 stool samples

(1) Universidade Federal de Uberlândia, Escola Técnica de Saúde, Av. Amazonas, Bloco 4K, Umuarama, Uberlândia, Minas Gerais, Brazil.

(2) Universidade Federal do Triângulo Mineiro, Rua Frei Paulino 30, Abadia, Uberaba, Minas Gerais, Brazil.

(3) Bolsista de Produtividade em Pesquisa (CNPq).

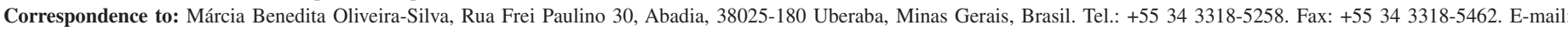
mbosilva@yahoo.com.br. 


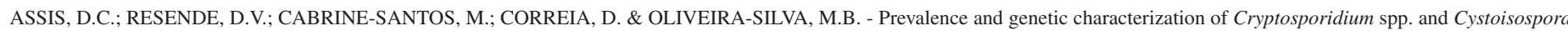
belli in HIV-infected patients. Rev. Inst. Med. Trop. Sao Paulo, 55(3): 149-54, 2013.

were collected from 59 HIV-infected patients referred to the hospital of UFTM. For the detection of Cryptosporidium spp. and C. belli oocysts, the stool samples were concentrated using the formol-ether method ${ }^{24}$ and fecal smears were stained using the modified Ziehl-Neelsen technique ${ }^{13}$.

Clinical and epidemiological data of the patients, including age, gender, mean $\mathrm{CD}^{+}$and $\mathrm{CD}^{+} \mathrm{T}$ lymphocyte count, viral load, use of antiretroviral therapy (ART), and presence of diarrheic syndrome were collected by reviewing the patients' medical records. All patients enrolled in this study received antiretroviral therapy according to Brazilian Ministry of Health's consensus recommendations. The ART regimes were composed of two nucleoside reverse transcriptase inhibitors plus one protease inhibitor or two nucleoside reverse transcriptase inhibitors plus one non-nucleoside reverse transcriptase inhibitor. Data not present in the medical records were excluded from the statistical analysis.

Determination of rainfall indices: The rainfall indices of the municipality of Uberaba, Minas Gerais, were provided by the Instituto de Pesquisas Espaciais (INPE).

Genetic analysis: Genomic DNA was extracted from Cryptosporidium spp. and C. belli oocysts according to the protocol of BOOM et al. ${ }^{3}$, modified by PATEL et al. ${ }^{20}$. The extracted DNA was purified using the GFX Genomic Blood DNA Purification kit (Amersham Biosciences, Piscataway, NJ, USA) according to manufacturer instructions.

A highly polymorphic region of the SSU-rRNA gene of Cryptosporidium spp. was amplified by nested PCR as described by XIAO et al. ${ }^{31}$. A first product of approximately 1325 bp was amplified using the primers $18 \mathrm{SX} 1 \mathrm{~F}$ (5'-AAC CTG GTT GAT CCT GCC AGT AGT C-3') and 18SX1R (5'-TGA TCC TTC TGC AGG TTC ACC TAC G-3'). PCR was carried out in a final volume of $30 \mu \mathrm{L}$ containing $3 \mathrm{mM}$ $\mathrm{MgCl}_{2}, 200 \mu \mathrm{M}$ of each dNTP, 2.5 units Platinum Taq DNA polymerase (Invitrogen, Carlsbad, CA, USA), 50mM KCl, 200nM of each primer and $5 \mu \mathrm{L}$ DNA. The amplification conditions were an initial denaturation at $94{ }^{\circ} \mathrm{C}$ for three min and 35 cycles of denaturation at $94{ }^{\circ} \mathrm{C}$ for $45 \mathrm{~s}$, annealing at $55^{\circ} \mathrm{C}$ for $45 \mathrm{~s}$ and extension at $72{ }^{\circ} \mathrm{C}$ for $40 \mathrm{~s}$, followed by a final extension step for seven min. For amplification of an internal fragment of approximately $825 \mathrm{bp}, 2 \mu \mathrm{L}$ of the first PCR product diluted 1:2 was mixed with the $18 \mathrm{SX} 2 \mathrm{~F}$ (5'-GGA AGG GTT GTA TTT ATT AGA TAA AG-3') and 18SX2R primers (5'-AAG GAG TAA GGA ACA ACC TCC A-3'). The amplification conditions of the second PCR were the same as those used in the first PCR.

The eukaryote-specific primer 1FPL (5'-GCGGATCCGCGGCC GCTGGTTGATCCTGCCAGT-3') and the universal primer 1520RPL (5'-GCGGATCCGCGGCCGCGGCAGGTTCACCTAC-3') were used to amplify a specific fragment of approximately $1800 \mathrm{bp}$ of the $C$. belli SSU rDNA gene according to previously described protoco ${ }^{21}$ modified by RESENDE et al. $^{23}$. In short, the reaction was carried out in a final volume of $30 \mu \mathrm{L}$ containing $2 \mathrm{mM} \mathrm{MgCl}, 200 \mu \mathrm{M}$ of each dNTP, 5\% glycerol, 1 unit Platinum ${ }^{\circledR}$ Taq DNA polymerase (Invitrogen, Carlsbad, CA, USA) in a buffer of $10 \mathrm{mM}$ Tris- $\mathrm{HCl}, \mathrm{pH} 8.3$, and $50 \mathrm{mM} \mathrm{KCl}$, $670 \mathrm{nM}$ of each primer and $5 \mu \mathrm{L}$ of DNA. The amplification conditions consisted of an initial denaturation at $95{ }^{\circ} \mathrm{C}$ for three min and 40 cycles of denaturation at $94{ }^{\circ} \mathrm{C}$ for one min, annealing at $55^{\circ} \mathrm{C}$ for one min and extension at $72{ }^{\circ} \mathrm{C}$ for two min, followed by a final extension step of $10 \mathrm{~min}$ at $72{ }^{\circ} \mathrm{C}$.
Amplification was carried out in a PTC-200 thermocycler (MJ Research, Inc., Watertown, MA, USA) and the amplified products were separated by electrophoresis on $1 \%$ agarose gel stained with $0.5 \mu \mathrm{g} / \mathrm{mL}$ ethidium bromide and observed under ultraviolet light.

For analysis of the restriction fragments of Cryptosporidium spp., the second PCR product was digested with $S s p$ I and VspI (New England BioLabs, Inc., Ipswich, MA, USA) according to XIAO et al. ${ }^{31}$ and for C. belli, the 1800 bp fragment of the SSU rDNA gene was digested with ScrFI, MboII and RsaI (New England BioLabs, Inc.) according to RESENDE et al. ${ }^{23}$. The restriction fragments generated were separated by electrophoresis on $7.5 \%$ nondenaturing polyacrylamide gel and analyzed after silver staining.

Genetic relationships between isolates were determined using the GelCompar II 5.0 program (Applied Maths, Kortrijk, Belgium). The Dice similarity coefficient was used for the calculation of the similarity matrix and the UPGMA method (unweighted pair-group method with arithmetic mean) for dendrogram construction and analysis. For the purpose of comparison, C. belli isolate CB14 previously characterized by RESENDE et al. ${ }^{23}$ was used in the phylogenetic analyses.

Statistical methods: Data were analyzed with the Statistical Package of the Social Sciences (SPSS), version 17.0. The results are reported as absolute and relative frequencies and were compared by Pearson's chi-square and Mann-Whitney tests. A level of significance of $p<0.05$ was adopted.

\section{RESULTS}

In all, 120 stool samples were examined from 59 patients (an average of two samples/patient). Forty-two $(71.1 \%)$ of the participants were male and $17(28.8 \%)$ were female. The ages of the members of the study group varied from $14-56$ years with a mean of $35.7 \pm 8.9$ years.

Oocysts were detected in stool samples of $16.9 \%$ (10/59) of these patients, while Cryptosporidium spp. were present in $10.1 \%(6 / 59)$ and C. belli in 6.7\% (4/59). Diarrheic syndrome was observed in $23(38.9 \%)$ of the cases. Of these, $30.4 \%$ (7/23) were positive for intestinal protozoa in stool samples, including Cryptosporidium spp. in $21.7 \%(5 / 23)$ and C. belli in $8.7 \%(2 / 23)$. There was a significant association between diarrheic syndrome and the presence of these protozoa in stool samples $(p=0.02)$. In the group without diarrhea, the prevalence of these protozoa was $8.3 \%(3 / 36)$, with $2.78 \%(1 / 36)$ of the patients being positive for Cryptosporidium spp. and $5.56 \%$ (2/36) for C. belli. No case of mixed infection was observed.

The $\mathrm{CD}^{+} \mathrm{T}$ lymphocyte was quantified in $81.3 \%$ (48/59) of the patients included in this study. The mean count was $40 \pm 23.7$ cells $/ \mathrm{mm}^{3}$ in patients who tested positive for Cryptosporidium spp. or C. belli and 195.9 \pm 201.8 cells $/ \mathrm{mm}^{3}$ in patients with negative stool samples. A significant association was observed between a CD4 $4^{+} \mathrm{T}$ lymphocyte count $<200$ cells $/ \mathrm{mm}^{3}$ and the presence of Cryptosporidium spp. or C. belli in stool samples $(p=0.01)$. A CD8 ${ }^{+} \mathrm{T}$ lymphocyte count could be obtained for $76.2 \%(45 / 59)$ of the patients, but no association was observed between the number of these cells and the presence of these infections $(p=0.32)$.

The viral load was determined in $45.7 \%$ (27/59) of the patients 
studied, but there was no significant association with cryptosporidiosis or cystoisosporosis $(p=0.21)$. Thirty-one $(51.3 \%)$ of the 59 patients regularly used ART. However, only $40 \%$ (4/10) of the subjects with these intestinal infections regularly used this therapy. A significant association was observed between the lack of adherence to ART and the presence of Cryptosporidium spp. or C. belli $(p=0.04)$.

Analysis of the prevalence of these protozoa according to the time of year and the annual rainfall index showed a higher prevalence of Cryptosporidium spp. in February and April, whereas cystoisosporosis mainly occurred in January, February, May and July (Fig. 1).

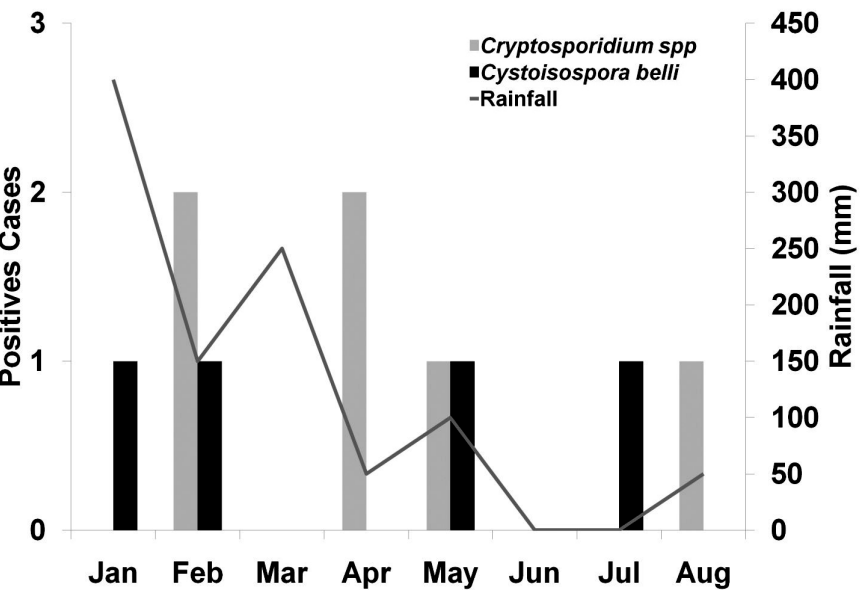

Fig. 1 - The Uberaba rainfall index and seasonal distribution of Cryptosporidium spp. and Cystoisospora belli in HIV-infected between January and August 2005.

Three $(30 \%)$ of the 10 clinical isolates were submitted to genetic characterization, including two Cryptosporidium spp. isolates and one $C$. belli isolate. In the case of the Cryptosporidium spp. isolates, the restriction profiles obtained by digestion with $S s p$ I resulted in fragments of approximately 448, 247, and 106 bp and digestion with VspI in fragments of 628 and 104 bp. This profile is compatible with Cryptosporidium parvum (bovine genotype) (Fig. 2).
The restriction profiles generated by digestion of the specific fragment of $C$. belli with $S c r F I$ and $R s a$ I showed $100 \%$ similarity with the profile of the isolate used as a control (Fig. 3). Digestion with ScrFI produced fragments of approximately 513, 708, and $818 \mathrm{bp}$, whereas digestion with $R s a$ I resulted in fragments of approximately 181, 339, and 1122 bp (Fig. 3). Digestion of the specific fragment with MboII generated fragments of approximately $181,251,426,602$, and $1013 \mathrm{bp}$, compatible with restriction profile $\mathrm{II}^{23}$.

\section{DISCUSSION}

In the present study, a high prevalence of Cryptosporidium spp. and C. belli was observed among HIV-infected patients living in the region of Uberaba and the presence of these parasites was correlated with the occurrence of diarrhea, a reduced $\mathrm{CD} 4^{+} \mathrm{T}$ lymphocyte count and lack of adherence to ART, demonstrating the opportunistic characteristic of these infections. However, it should be pointed out that even asymptomatic (non-diarrheic) subjects $(8.3 \%$ of the sample) eliminated oocysts in feces and therefore represent a source of infection for other individuals.

According to OLIVEIRA-SILVA et al. ${ }^{19}$, low CD4 ${ }^{+}$T lymphocyte counts are a predisposing factor for protozoal infections. This was demonstrated in the present study in which all patients with cryptosporidiosis or cystoisosporosis had low lymphocyte counts. This finding can be explained through the understanding of immunological disorders in HIV/AIDS patients, who are particularly deficient in a subpopulation of lymphocytes $\mathrm{CD}^{+} \mathrm{T}$, the main cell population that protects against intracellular parasites ${ }^{27}$.

The low rate of adherence to ART observed contributed to the high prevalence of opportunistic infections among the patients studied. Several studies have documented a decline in the prevalence of cryptosporidiosis after the introduction of ART since this therapy suppresses the replication of HIV, leading to an increase in circulating CD4 $4^{+} \mathrm{T}$ lymphocytes and intestinal repopulation, and subsequently the restoration of mucosal immunity ${ }^{17,26,28}$.

Parasitism with Cryptosporidium spp. was more frequent in February

Dice (Tol 1.0\%-1.0\%) (H>0.0\% S>0.0\%) [0.0\%-100.0\%] PCR-RFLP Cryptosporidium

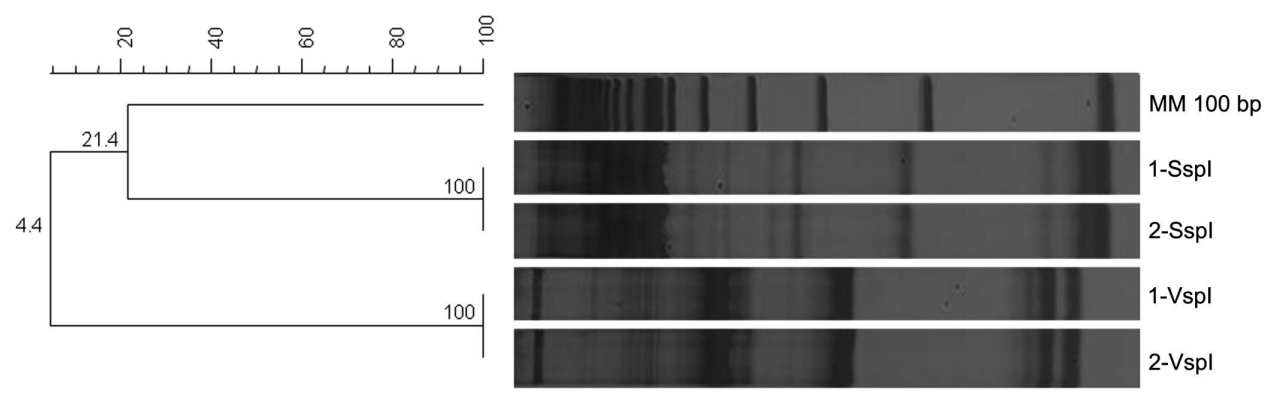

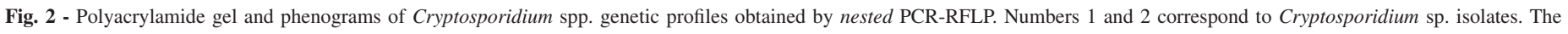
phenograms were created with the software GELCOMPAR II® (Applied Maths) with the Dice coefficient and Unweighted Pair-Group Method Arithmetic. MM - molecular marker. 
ASSIS, D.C.; RESENDE, D.V.; CABRINE-SANTOS, M.; CORREIA, D. \& OLIVEIRA-SILVA, M.B. - Prevalence and genetic characterization of Cryptosporidium spp. and Cystoisospora belli in HIV-infected patients. Rev. Inst. Med. Trop. Sao Paulo, 55(3): 149-54, 2013.

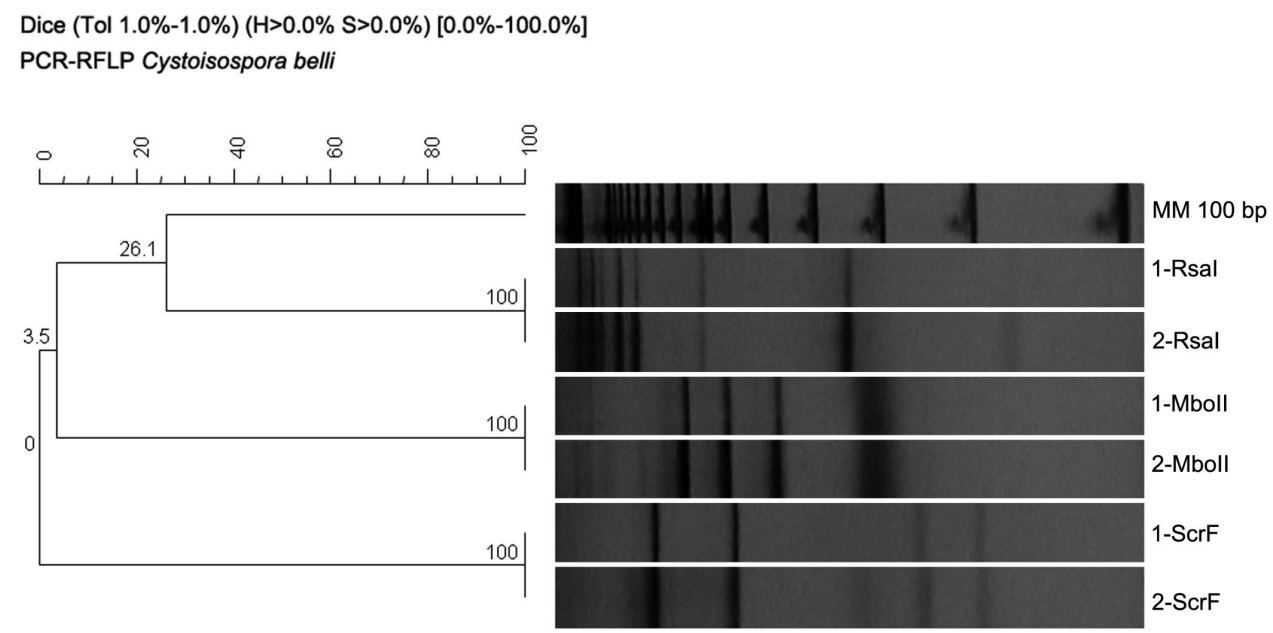

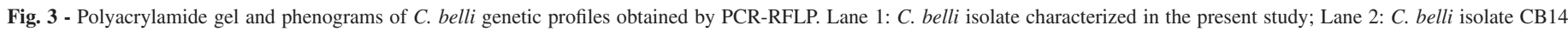

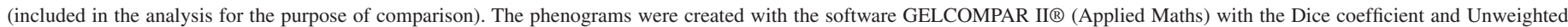
Pair-Group Method Arithmetic. MM - molecular marker.

and April, the period following the months of high rainfall. Although the occurrence of cryptosporidiosis cases did not differ statistically between seasons, the results are consistent with other studies reporting a higher frequency of cryptosporidiosis in the hotter and more humid months of the year ${ }^{19,30,32}$. This seasonal pattern was not observed for cystoisosporosis, whose chronic character and recurrences are believed to be due to the ability of $C$. belli to infect extraintestinal sites, where the parasite forms tissue cysts that eventually return to the intestine and trigger new pathogenic processes. The prevalence of this infection in HIV $(+)$ may therefore be related more to the immune status of the individual than to the seasonal patterns.

The use of different molecular techniques has led to a better understanding of the epidemiology of cryptosporidiosis, with the identification of different species/genotypes and subtypes of Cryptosporidium spp. that infect humans ${ }^{21}$. Although more than five Cryptosporidium species/genotypes have been described in humans, C. parvum and C. hominis are the species responsible for most cases of cryptosporidiosis in the world ${ }^{4,5,10}$. Genetic analysis of the two clinical isolates of Cryptosporidium spp. identified them as C. parvum, a potentially zoonotic species. The presence of these isolates in HIVinfected patients might be explained by the fact that Uberaba is basically a farming region, which is characterized by a high prevalence of bovine cryptosporidiosis. It is possible that the water reservoirs of the region are contaminated with Cryptosporidium spp. oocysts originating from herds found close to the rivers which supply these reservoirs.

Evidence indicates that parasite-related factors such as genotype or differences in virulence between isolates are associated with the intensity of the clinical manifestations of cryptosporidiosis. Variations in the number of excreted oocysts, clinical manifestations and response to treatment are observed in HIV-infected patients with cryptosporidiosis who present similar levels of immunosuppression ${ }^{12}$. In the present study, only one of the patients submitted to genetic characterization presented episodes of diarrhea. Although intraspecies differences might be partly responsible for the variations in clinical manifestations between patients, the lack of adherence to antiretroviral therapy was an important factor. It is known that continuous use of ART suppresses the replication of HIV, leading to an increase in circulating $\mathrm{CD}^{+} \mathrm{T}$ lymphocytes and intestinal repopulation, and subsequently the restoration of mucosal immunity ${ }^{26}$.

In the study of RESENDE et al. ${ }^{23}$, the restriction profiles obtained by digestion of the SSU-rDNA gene of $C$. belli with MboII demonstrated the presence of genetic heterogeneity among the isolates analyzed. Although in that study it was not possible to correlate the restriction profiles with the clinical manifestations of the patients, the results obtained demonstrate the occurrence of different genotypes infecting humans and open perspectives for the discovery of different routes of transmission of cystoisosporosis. FRENKEL et al. ${ }^{9}$ suggested a facultatively heteroxenous life cycle for this species, with the formation of extraintestinal tissue cysts in intermediate and/or paratenic hosts. As observed for cryptosporidiosis, the presence of anthropozoonotic transmission would explain the presence of this infection in areas with good sanitary conditions. However, studies investigating a larger number of clinical isolates from different regions are needed in order to determine the extent of heterogeneity between $C$. belli genotypes and the possible relationship of these genotypes with the clinical manifestations and epidemiological characteristics of cystoisosporosis.

\section{RESUMO}

\section{Prevalência e caracterização genética de Cryptosporidium spp. e Cystoisospora belli em pacientes infectados pelo HIV}

Cryptosporidium spp. e Cystoisospora belli são protozoários monoxenos reconhecidos como agentes causadores de diarréia crônica em indivíduos imunocomprometidos, especialmente aqueles infectados pelo HIV. Os objetivos deste estudo foram o de avaliar a frequência destes protozoários em pacientes HIV - positivos na região do Triângulo Mineiro, Brasil, e correlacionar a presença destas infecções com dados clínicos, epidemiológicos e laboratoriais dos pacientes. Oocistos foram detectados em amostras fecais de 10 (16,9\%) dos 59 pacientes estudados, 
ASSIS, D.C.; RESENDE, D.V.; CABRINE-SANTOS, M.; CORREIA, D. \& OLIVEIRA-SILVA, M.B. - Prevalence and genetic characterization of Cryptosporidium spp. and Cystoisospora belli in HIV-infected patients. Rev. Inst. Med. Trop. Sao Paulo, 55(3): 149-54, 2013.

sendo $10.1 \%(6 / 59)$ das amostras positivas para Cryptosporidium spp. e $6,7 \%(4 / 59)$ das amostras positivas para $C$. belli. A frequência destes parasitos foi maior entre pacientes com síndrome diarreica e contagem de linfócitos T CD4 ${ }^{+}<200$ cells $/ \mathrm{mm}^{3}$, o que demonstra o caráter oportunista destas infecções. Foi observada uma associação significativa entre a falta de aderência à terapia antiretroviral e a presença de Cryptosporidium spp. e/ou C. belli. Parasitismo por Cryptosporidium spp. foi mais frequente em fevereiro e abril, meses subsequentes ao período chuvoso. O mesmo não foi observado para $C$. belli. A caracterização genética de dois isolados levou à identificação de Cryptosporidium parvum, uma das principais espécies associadas com a transmissão zoonótica da criptosporidiose.

\section{AUTHORS' CONTRIBUTIONS}

MBOS and DC were responsible for the study design; DCA and DVR participated in the collection of the data and stool samples; DCA, DVR and MCS participated in the processing of samples; DVR was involved in the DNA extraction and molecular analysis; DCA and DVR analyzed and interpreted the data; DCA, MBOS and DVR drafted and revised the manuscript. All authors read and approved the final manuscript. MBOS is guarantor of the paper.

\section{FUNDING: None.}

\section{CONFLICTS OF INTEREST: None declared.}

\section{ETHICAL APPROVAL}

The study was approved by the Research Ethics Committee of the Universidade Federal do Triângulo Mineiro, Brazil (protocol 712). All subjects provided written informed consent and were included in the study.

\section{REFERENCES}

1. Araújo AJ, Kanamura HY, Almeida ME, Gomes AH, Pinto THL, Da Silva AJ. Genotypic identification of Cryptosporidium spp. isolated from HIV-infected patients and immunocompetent children of São Paulo, Brazil. Rev Inst Med Trop Sao Paulo. 2008;50:139-43

2. Bachur TPR, Vale JM, Coêlho IC, Queiroz TRBS, Chaves CS. Enteric parasitic infections in HIV/AIDS patients before and after the highly active antiretroviral therapy. Braz J Infect Dis. 2008;12:115-22.

3. Boom R, Sol CJ, Salimans MM, Jansen CL, Wertheim-van Dillen PM, van der Noordaa J. Rapid and simple method for purification of nucleic acids. J Clin Microbiol. 1990;28:495-503.

4. Cacciò SM, Thompson RC, McLauchlin J, Smith HV. Unravelling Cryptosporidium and Giardia epidemiology. Trends Parasitol. 2005;21:430-7.

5. Cama VA, Bern C, Roberts J, Cabrera L, Sterling CR, Ortega Y, et al. Cryptosporidium species and subtypes and clinical manifestations in children, Peru. Emerg Infect Dis. 2008;14:1567-74.

6. Capuano DM, Okino MHT, Bettini MCB. Freqüência de Cryptosporidium e Isospora belli em pacientes soropositivos para o HIV na região de Ribeirão Preto, SP-Brasil. Rev Inst Adolfo Lutz. 2001;60:11-5

7. Cardoso LV, Marques FR, Cavasini CE, Almeida MC, Bassi NA, Gongorá DVN, et al. Correlation of intestinal parasitic pathogens in HIV-seropositive adult with and without diarrhea in Northeast region of São Paulo State, Brazil. Rev Pan Infect. 2004;6:8-11.
8. Cimerman S, Cimerman B, Lewi DS. Enteric parasites and AIDS. Sao Paulo Med J. 1999; $117: 266-73$

9. Frenkel JK, Silva MB, Saldanha J, de Silva ML, Correia Filho VD, Barata CH, et al. Isospora belli infection: observation of unicellular cysts in mesenteric lymphoid tissues of a Brazilian patient with AIDS and animal inoculation. J Eukaryot Microbiol. 2003;50:682-4

10. Gatei W, Greensill J, Ashford RW, Cuevas LE, Parry CM, Cunliffe NA, et al. Molecular analysis of the 18S rRNA gene of Cryptosporidium parasites from patients with or without human immunodeficiency virus infections living in Kenya, Malawi, Brazil, the United Kingdom, and Vietnam. J Clin Microbiol. 2003,41:1458-62.

11. Gonçalves EMN, Silva AJ, Eduardo MBP, Uemura IH, Moura INS, Castilho VLP, et al. Multilocus genotyping of Cryptosporidium hominis associated with diarrhea outbreak in a day care unit in São Paulo. Clinics (Sao Paulo) 2006;61:119-26.

12. Goodgame RW, Genta RM, White AC, Chappell CL. Intensity of infection in AIDSassociated cryptosporidiosis. J Infect Dis. 1993;167:704-9.

13. Henriksen SA, Pohlenz JFL. Staining of Cryptosporidia by a modified Ziehl-Neelsen technique. Acta Vet Scand. 1981;22:594-6.

14. Long PL. Coccidiosis of man and domestic animals. Boca Raton: CRC Press; 1990.

15. Lucca P, De Gaspari EN, Bozolli LM, Funada MR, Silva SO, Lulino W, et al. Molecular characterization of Cryptosporidium spp. from HIV infected patients from an urban area of Brazil. Rev Inst Med Trop Sao Paulo. 2009;51:341-3.

16. Mascarini LM, Donalísio MR. Giardíase e criptosporidiose em crianças institucionalizadas em creches no Estado de São Paulo. Rev Soc Bras Med Trop. 2006;39:577-9.

17. Mirdha BR, Kabra SK, Samantray JC. Isosporiasis in children. Indian Pediatr. 2002;39:941-4

18. Moura FT, Falavigna DLM, Mota LT, Toledo MJO. Enteroparasite contamination in peridomiciliar soils of two indigenous territories, State of Paraná, southern Brazil. Rev Panam Salud Publica. 2010;27:414-22.

19. Oliveira-Silva MB, de Oliveira LR, Resende JC, Peghini BC, Ramirez LE, Lages-Silva $\mathrm{E}$, et al. Seasonal profile and level of CD4+ lymphocytes in the occurrence of cryptosporidiosis and cystoisosporidiosis in HIV/AIDS patients in the Triângulo Mineiro region, Brazil. Rev Soc Bras Med Trop. 2007;40:512-5.

20. Patel S, Pedraza-Díaz S, McLauchlin J, Casemore DP. Molecular characterisation of Cryptosporidium parvum from two large suspected waterborne outbreaks. Outbreak Control Team South and West Devon 1995, incident management team and further epidemiological and microbiological studies subgroup: North Thames 1997. Commun Dis Public Health. 1997;1:231-3.

21. Peng MM, Xiao L, Freeman AR, Arrowood MJ, Escalante AA, Weltman AC, et al. Genetic polymorphism among Cryptosporidium parvum isolates: evidence of two distinct human transmission cycles. Emerg Infect Dis. 1997;3:567-73.

22. Relman DA, Schmidt TM, Gajadhar A, Sogin M, Cross J, Yoder K, et al. Molecular phylogenetic analysis of Cyclospora, the human intestinal pathogen, suggests that it is closely related to Eimeria species. J Infect Dis. 1996;173:440-5.

23. Resende DV, Pedrosa AL, Correia D, Cabrine-Santos M, Lages-Silva E, Meira WS, et al Polymorphisms in the 18S rDNA gene of Cystoisospora belli and clinical features of cystoisosporosis in HIV-infected patients. Parasitol Res. 2011;108:679-85.

24. Ritchie LS. An ether sedimentation technique for routine stool examination. Bull US Army Med Dep. 1948;8:326.

25. Rolando RFR, Silva S, Peralta RHS, Silva AJ, Cunha FS, Bello AR, et al. Detection and differentiation of Cryptosporidium by real-time polymerase chain reaction in stool samples from patients in Rio de Janeiro, Brazil. Mem Inst Oswaldo Cruz. 2012;107:476-9. 
ASSIS, D.C.; RESENDE, D.V.; CABRINE-SANTOS, M.; CORREIA, D. \& OLIVEIRA-SILVA, M.B. - Prevalence and genetic characterization of Cryptosporidium spp. and Cystoisospora belli in HIV-infected patients. Rev. Inst. Med. Trop. Sao Paulo, 55(3): 149-54, 2013.

26. Schmidt W, Wahnschaffe U, Schäfer M, Zippel T, Arvand M, Meyerhans A, et al. Rapid increase of mucosal CD4 $\mathrm{T}$ cells followed by clearance of intestinal cryptosporidiosis in an AIDS patient receiving highly active antiretroviral therapy. Gastroenterology. 2001;120:984-7.

27. Silva CV, Ferreira MS, Borges AS, Costa-Cruz JM. Intestinal parasitic infections in HIV/ AIDS patients: experience at a teaching hospital in central Brazil. Scand J Infect Dis. $2005 ; 37: 211-5$

28. Souza LR, Rodrigues MA, Morceli J, Kemp R, Mendes RP. Cryptosporidiosis of the biliary tract mimicking pancreatic cancer in an AIDS patient. Rev Soc Bras Med Trop. 2004;37:182-5.

29. Tuli L, Gulati AK, Sundar S, Mohapatra TM. Correlation between CD4 counts of HIV patients and enteric protozoan in different seasons. An experience of a tertiary care hospital in Varanasi (India). BMC Gastroenterology. 2008;8:36.

30. Tzipori S, Ward H. Cryptosporidiosis: biology, pathogenesis and disease. Microbes Infect. 2002;4:1047-58.

31. Xiao L, Fayer R. Molecular characterisation of species and genotypes of Cryptosporidium and Giardia and assessment of zoonotic transmission. Int J Parasitol. 2008;38:123955 .

32. Xiao L, Morgan UM, Fayer R, Thompson RC, Lal AA. Cryptosporidium systematics and implications for public health. Parasitol Today. 2000;16:287-92.

Received: 16 July 2012

Accepted: 10 October 2012 